\title{
Pengaruh Penambahan Cinnamon Essential Oil Pada Edible Coating KITOSAN TERHADAP UMUR SIMPAN FILLET IKAN KAKAP MERAH (Lutjanus sp.)
}

\author{
Jeny Ernawati Tambunan ${ }^{\mathrm{a}, *}$, Anies Chamidaha \\ aprogram Studi Teknologi Hasil Perikanan, Fakultas Perikanan dan Ilmu Kelautan, Universitas Brawijaya \\ J1. Veteran No. 1 Kota Malang Indonesia.
}

*Koresponden penulis : jenyetambunan@ub.ac.id

\begin{abstract}
Abstrak
Kitosan adalah polisakarida alami hasil dari proses deasetilasi dari kitin yang juga memiliki potensi digunakan dalam food packaging seperti edible film dan edible coating karena memiliki polimer hidrokoloid yang bersifat antioksidan, antimikroba, dan merupakan barrier yang baik terhadap oksigen. Salah satu kandungan kayu manis adalah minyak atsiri. Minyak atsiri dapat ditambahkan pada edible coating sebagai antimikroba. Tujuan penelitain ini adalah untuk mengetahui pengaruh penambahan cinnamon essential oil pada edible coating kitosan terhadap umur simpat fillet ikan kakap merah. Rancangan percobaan pada penelitian ini menggunakan RAL (Rancangan Acak Lengkap) non faktorial. Fillet ikan kakap merah diberikan tiga perlakuan yaitu: tanpa coating, coating tanpa penambahan cinnamon essential oil, dan coating dengan kombinasi 1.5 gram kitosan dan $1.5 \%$ cinnamon essential oil. Hasil penelitian menunjukan Penambahan cinnamon essential oil pada edible coating kitosan memberikan pengaruh terhadap kualitas fillet ikan kakap merah selama masa penyimpanan dilihat dari parameter TPC, TVB dan pH. Fillet yang dilapisi dengan edible coating kitosan dengan penambahan cinnamon essential oil masih layak dikonsumsi sampai dengan penyimpanan hari ke 9 dengan nilai TPC Log 5,7, TVB 30,33 mgN/100g dan pH 6,53.
\end{abstract}

Kata kunci: Cinnamon essential oil, Kitosan, pH, TPC, dan TVB

\begin{abstract}
Chitosan is a natural polysaccharide resulting from the deacetylation process which also has the potential to be used in food packaging such as edible films and edible coatings because it has hydrocolloid polymers that are antioxidant, antimicrobial, and a good barrier to oxygen. One of the contents of cinnamon is essential oil. Essential oils can be added to edible coatings as antimicrobials. The purpose of this study was to determine the effect of adding cinnamon essential oil to chitosan edible coating on the shelf life of red snapper fillets. The experimental design in this study used RAL (Simple Completely Randomized Design). Red snapper fillets were given three treatments, namely: without coating, coating without adding cinnamon essential oil, and coating with a combination of 1.5 grams of chitosan and $1.5 \%$ cinnamon essential oil. The results showed the addition of cinnamon essential oil in chitosan edible coating has an effect on the quality of red snapper fillets during the storage period seen from the parameters of TPC, TVB and pH. Fillets coated with chitosan edible coating with the addition of cinnamon essential oil are still suitable for consumption until the 9th day of storage with a TPC Log 5.7, TVB $30.33 \mathrm{mgN} / 100 \mathrm{~g}$ and $\mathrm{pH} 6.53$.
\end{abstract}

Keywords: Chitosan, Cinnamon essential oil, pH, TPC, and TVB

\section{PENDAHULUAN}

Ikan kakap merah (Lutjanus sp.) merupakan jenis ikan demersal dari famili Lutjanidae yang memiliki nilai ekonomis tinggi di Indonesia. Harga ikan kakap merah di pasar internasional 5,50-18,10 US\$ pada ukuran konsumsi [1]. Ikan ini biasanya dipasarkan dalam kondisi hidup dan berbentuk fillet [2]. Permintaan pasar yang tinggi berpengaruh pada jumlah penangkapan ikan kakap merah tiap tahunnya [3]. Jenis ikan kakap merah yang umum tertangkap adalah Lutjanus malabaricus, L.johni, L. sanguineus, dan L.sebae [4]. Ikan kakap merah mempunyai kandungan gizi $77,53 \%$ air, $1,42 \%$ abu, $20,55 \%$ protein, $0,27 \%$, lemak, dan $0,23 \%$ karbohidrat dan PUFA/SFA 0,97 [5]. Namun disamping gizi ikan yang tinggi, ikan mempunyai kelemahan yaitu mudah rusak atau membusuk karena kandungan air yang cukup tinggi 70-80\% [6]. Kerusakan ini 
dikarenakan kandungan kadar air yang sangat tinggi yaitu $80 \%$ pada tubuh ikan, $\mathrm{pH}$ tubuh mendekati normal $( \pm 7)$ dan kandungan gizi yang tinggi sehingga dapat dijadikan tempat pertumbuhan dan perkembangan mikroba [7].

Saat ini banyak zat kimia berbahaya digunakan sebagai bahan pengawet pada produk hasil perikanan. Di Indonesia, nelayan kerap menambahkan bahan pengawet berbahaya seperti formalin untuk mencegah pembusukan ikan [8]. Kitosan adalah polisakarida alami hasil dari proses deasetilasi (penghilangan gugus $\mathrm{COCH}_{3}$ ) dari kitin [9]. Sifat kitosan tidak toksik, memiliki biological activity, biocompatibility, biodegradability, dan dapat dimodifikasi secara kimia dan fisika [10]. Kitosan juga memiliki potensi digunakan dalam food packaging seperti edible film dan edible coating karena memiliki polimer hidrokoloid yang bersifat antioksidan, antimikroba, dan merupakan barrier yang baik terhadap oksigen [11].

Edible packaging merupakan salah satu jenis kemasan yang ramah lingkungan, dapat melindungi produk pangan dan dapat langsung dimakan [12]. Pelapisan produk pangan dengan edible packaging mampu memperpanjang masa simpan dan memperbaiki kualitas produk pangan. Edible packaging berdasarkan fungsinya terbagi atas edible coating yang berfungsi sebagai pelapis dan edible film yang berbentuk lembaran [13]. Edible coating berbahan kitosan bersifat antimikroba dan dapat mencegah kontaminasi patogen pada berbagai bahan pangan yang memiliki jaringan seperti daging, buahbuahan, dan sayuran [14].

Pada pembuatan edible coating biasanya ditambahkan beberapa macam bahan tambahan seperti antimikroba dan antioksidan. Rempah-rempah dalam bentuk bubuk maupun minyak atsiri seperti kayu manis, lada, cengkeh, oregano, minyak basil, minyak sereh, bawang putih, dan komponen minyak atsiri dapat ditambahkan pada edible coating sebagai antimikroba [15]. Senyawa aktif minyak atsiri seperti karvakrol, sinamaldehida, dan sitral mempunyai sifat antimikroba yang tinggi [16]. Kayu manis kaya akan cinnamaldehyde seperti $b$ caryophyllene, linalool dan terpen lainnya. Cinnamaldehyde adalah unsur utama dari minyak kayu manis yang menghasilkan bau dan rasa khas dari kayu manis. Kandungan kayu manis antara lain minyak atsiri, safrole, sinamaldehida, tanin, dammar, kalsium oksalat, flavonoid, triterpenoid, dan saponin. Komponen minyak atsiri tersebut memiliki aktivitas sebagai antibakteri sehingga dapat mencegah proses pembusukan [17]. Berdasarkan hal tersebut, maka diperlukan penelitian untuk mengetahui pengaruh penambahan cinnamon essential oil pada edible coating kitosan terhadap umur simpan fillet ikan kakap merah.

\section{METODE}

\section{Bahan}

Bahan-bahan yang digunakan pada penelitian ini adalah kitosan, cinnamon essential oil dari Happy Green (Importer of Essential Oils, Absolutes, and Carrier Oils), fillet ikan kakap merah dari Pasar Oro-oro Dowo Malang, aquades, asam asetat, gliserol, tween 80, TCA, asam borat, $\mathrm{K}_{2} \mathrm{CO}_{3}, \mathrm{HCl}$, vaselin, kertas saring, kertas cakram, alumunium foil, plastik wrap, Methyl red, Ethyl alcohol, Bromcresol green, media MHA, media PCA, dan $\mathrm{NaCl}$.

Alat

Alat-alat yang digunakan pada penelitian ini adalah, gelas ukur $100 \mathrm{ml}$, beaker glass $250 \mathrm{~mL}$, beaker glass $50 \mathrm{ml}$, timbangan digital, oven, $\mathrm{pH}$ meter, spatula, hot plate, magnetic stirrer, pipet serologis, pipet volume, cawan petri, triangle, autoklaf, tabung reaksi, Erlenmeyer $250 \mathrm{~mL}$, rak tabung reaksi, pinset, bunsen, inkubator, bola hisap, mortar dan alu, buret, statif, pipet tetes, dan cawan conway.

\section{Rancangan Penelitian}

Rancangan percobaan pada penelitian ini menggunakan RAL (Rancangan Acak Lengkap) non faktorial. Fillet ikan kakap merah diberikan tiga perlakuan yaitu: tanpa coating, coating tanpa penambahan cinnamon essential oil, dan coating dengan kombinasi 1.5 gram kitosan dan $1.5 \%$ cinnamon essential oil, kemudian diulang sebanyak tiga kali. Sampel kemudian disimpan pada suhu $6^{\circ} \mathrm{C}$ selama 12 hari. 
Dilakukan pengujian TPC, TVB, dan $\mathrm{pH}$ pada hari ke 0 , hari ke 3 , hari ke 6 , hari ke 9 , dan hari ke 12. Rancangan penelitian dapat dilihat pada Tabel 1.

Tabel 1. Rancangan Penelitian

\begin{tabular}{|c|c|c|c|c|c|c|}
\hline \multirow[t]{2}{*}{ Perlakuan } & \multirow[t]{2}{*}{ Ulangan } & \multicolumn{5}{|c|}{ Lama Penyimpanan } \\
\hline & & $\mathrm{H} 0$ & $\mathrm{H} 3$ & $\mathrm{H} 6$ & $\mathrm{H} 9$ & $\mathrm{H} 12$ \\
\hline Tanpa & 1 & $\mathrm{C} 0$ & $\mathrm{C} 0$ & $\mathrm{C} 0$ & $\mathrm{C} 0$ & $\mathrm{C} 0$ \\
\hline \multirow[t]{5}{*}{ coating $(\mathrm{C} 0)$} & & $\mathrm{HO}$ & $\mathrm{H} 3$ & H6 & $\mathrm{H} 9$ & H12 \\
\hline & 2 & $\mathrm{C} 0$ & $\mathrm{C} 0$ & $\mathrm{C} 0$ & $\mathrm{C} 0$ & $\mathrm{C} 0$ \\
\hline & & $\mathrm{H} 0$ & $\mathrm{H} 3$ & H6 & $\mathrm{H} 9$ & $\mathrm{H} 12$ \\
\hline & 3 & $\mathrm{C} 0$ & $\mathrm{C} 0$ & $\mathrm{C} 0$ & $\mathrm{C} 0$ & $\mathrm{C} 0$ \\
\hline & & $\mathrm{HO}$ & $\mathrm{H} 3$ & H6 & $\mathrm{H} 9$ & H12 \\
\hline Coating & 1 & $\mathrm{C} 1$ & $\mathrm{C} 1$ & $\mathrm{C} 1$ & $\mathrm{C} 1$ & $\mathrm{C} 1$ \\
\hline tanpa & & $\mathrm{HO}$ & $\mathrm{H} 3$ & H6 & $\mathrm{H} 9$ & H12 \\
\hline penambahan & 2 & $\mathrm{C} 1$ & $\mathrm{C} 1$ & $\mathrm{C} 1$ & $\mathrm{C} 1$ & $\mathrm{C} 1$ \\
\hline cinnamon & & $\mathrm{HO}$ & $\mathrm{H} 3$ & H6 & $\mathrm{H} 9$ & $\mathrm{H} 12$ \\
\hline essential oil & 3 & $\mathrm{C} 1$ & $\mathrm{C} 1$ & $\mathrm{C} 1$ & $\mathrm{C} 1$ & $\mathrm{C} 1$ \\
\hline (C1) & & $\mathrm{HO}$ & $\mathrm{H} 3$ & H6 & $\mathrm{H} 9$ & H12 \\
\hline Coating & 1 & $\mathrm{C} 2$ & $\mathrm{C} 2$ & $\mathrm{C} 2$ & $\mathrm{C} 2$ & $\mathrm{C} 2$ \\
\hline kombinasi & & $\mathrm{H} 0$ & $\mathrm{H} 3$ & H6 & $\mathrm{H} 9$ & $\mathrm{H} 12$ \\
\hline kitosan dan & 2 & $\mathrm{C} 2$ & $\mathrm{C} 2$ & $\mathrm{C} 2$ & $\mathrm{C} 2$ & $\mathrm{C} 2$ \\
\hline cinnamon & & $\mathrm{HO}$ & $\mathrm{H} 3$ & H6 & $\mathrm{H} 9$ & H12 \\
\hline essential oil & 3 & $\mathrm{C} 2$ & $\mathrm{C} 2$ & $\mathrm{C} 2$ & $\mathrm{C} 2$ & $\mathrm{C} 2$ \\
\hline (C2) & & $\mathrm{HO}$ & $\mathrm{H} 3$ & H6 & $\mathrm{H} 9$ & $\mathrm{H} 12$ \\
\hline
\end{tabular}

\section{Parameter Uji}

Parameter uji pada penelitian ini meliputi TPC, TVB dan $\mathrm{pH}$

\section{Total Plate Count (TPC)}

Prinsip kerja uji TPC (Total Plate Count) adalah perhitungan jumlah koloni bakteri yang ada dalam sampel dengan pengenceran sesuai keperluan dan dilakukan secara duplo. Jumlah koloni yang dapat dihitung adalah cawan petri yang mempunyai koloni bakteri antara 30-300 [18].

\section{Perhitungan TPV (Total Plate Count)}

$$
\mathrm{N}=\frac{\sum \mathrm{C}}{(1 \times \mathrm{n} 1+0,1 \times \mathrm{n} 2) \times d}
$$

Keterangan:

$$
\begin{array}{ll}
\mathrm{N} & =\text { Jumlah koloni } \mathrm{mL} / \mathrm{g} \\
\sum \mathrm{C} & =\text { Jumlah total koloni dari semua cawan yang } \\
\text { dihitung } & \\
\mathrm{n} 1 & =\text { Jumlah cawan pada pengenceran pertama } \\
\mathrm{n} 2 & =\text { Jumlah cawan pada pengenceran kedua } \\
\mathrm{d} & =\text { tingkat pengenceran yang diperoleh dari } \\
\text { cawan yang pertama dihitung }
\end{array}
$$

\section{Total Volatile Base (TVB)}

Pengujian TVB bertujuan untuk menentukan jumlah kandungan senyawasenyawa basa volatil yang terbentuk akibat dari degradasi protein. Prinsip dari analisis TVB adalah menguapkan senyawa-senyawa basa volatil pada suhu kamar selama 24 jam. Senyawa tersebut kemudian diikat oleh asam borat dan kemudian dititrasi dengan larutan $\mathrm{HCl}$. Setelah disimpan larutan asam borat dalam inner chamber cawan Conway yang berisi blanko $\left(\mathrm{V}_{0}\right)$ dan Filtrat $\left(\mathrm{V}_{1}\right)$ dititrasi dengan larutan $\mathrm{HCl} 0,02 \mathrm{~N}$ sehingga larutan asam borat berubah warna menjadi merah muda [19].

$T V B=\frac{(\mathrm{V} 1-\mathrm{V} 0) \times \mathrm{N} . \mathrm{HCl} \times 14,007 \times \text { pengenceran } \times 100}{\text { Berat contoh }}$

$\begin{array}{ll}\text { Keterangan: } & \\ \text { TVB } & =\mathrm{ggN} / 100 \mathrm{gr} \\ \text { Berat contoh } & =\text { gram } \\ \text { V1 } & =\text { Volume titrasi Contoh } \\ \text { V0 } & =\text { Volume titrasi blanko } \\ \text { pH } & \end{array}$

Pada pengujian derajat keasaman $(\mathrm{pH})$ pada penelitian ini dilakukan dengan menggunakan alat $\mathrm{pH}$ meter. Penentuan $\mathrm{pH}$ dapat dilakukan dengan menggunakan $\mathrm{pH}$ meter [20]. Sebelum $\mathrm{pH}$ meter digunakan, harus dikalibrasi terlebih dahulu dengan larutan buffer $\mathrm{pH}$ 7. Besarnya $\mathrm{pH}$ adalah pembacaan jarum penunjuk $\mathrm{pH}$ setelah jarum skala konstan kedudukannya.

\section{HASIL DAN PEMBAHASAN}

Kemunduran mutu pada daging ikan dapat dilihat dari parameter nilai TPC, TVB dan $\mathrm{pH}$. Pada penelitian terdahulu ditemukan bahawa ada perbedaan nilai $\mathrm{pH}$ dan total volatile base nitrogen (TVB) pada ikan lele tanpa penyiangan dan dengan penyiangan yang disimpan dengan metode penyimpanan suhu [21]. Penyimpanan ikan gurami dalam suhu chilling yang menghasilkan pola kemunduran mutu pada ikan gurami dari fase pre rigor awal hingga ketika pembusukan yang berlangsung cepat berdasarkan perbedaan kisaran nilai organoleptik, $\mathrm{pH}, \log$ TPC, TVB [22]. Nilai rata-rata TPC, TVB dan pH dari sampel ikan kakap merah dengan tiga perlakuan berbeda yaitu, tanpa coating (C0), coating tanpa penambahan cinnamon essential oil (C1), dan coating dengan kombinasi 1.5 gram kitosan dan $1.5 \%$ 
cinnamon essential oil (C2) dapat dilihat pada Tabel 2.

Tabel 2. Nilai rata-rata TPC, TVB dan $\mathrm{pH}$ dari sampel ikan kakap merah dengan tiga perlakuan berbeda

\begin{tabular}{ccccc}
\hline Sampel & Hari & TPC & TVB & $\mathrm{pH}$ \\
\hline $\mathrm{C} 0$ & 0 & 3,5 & 9,8 & 6,2 \\
& 3 & 3,9 & 18,67 & 6,06 \\
& 6 & 5,2 & 27,53 & 6,5 \\
& 9 & 6,3 & 45,27 & 6,83 \\
$\mathrm{C} 1$ & 12 & 6,7 & 62,53 & 7,27 \\
& 0 & 3,5 & 9,33 & 6,17 \\
& 3 & 3,9 & 14,93 & 6,06 \\
& 6 & 4,8 & 24,27 & 6,4 \\
$\mathrm{C} 2$ & 9 & 5,8 & 36,87 & 6,7 \\
& 12 & 6,1 & 52,13 & 7,13 \\
& 0 & 3,5 & 8,87 & 6,06 \\
& 3 & 3,8 & 13,06 & 6,03 \\
& 6 & 4,6 & 21,7 & 6,23 \\
& 9 & 5,7 & 30,33 & 6,53 \\
& 12 & 5,9 & 48,57 & 7 \\
\hline
\end{tabular}

\section{Total Plate Count (TPC)}

Berdasarkan hasil penelitian diketahui bahwa rerata nilai TPC fillet ikan kakap merah adalah $\log 3,5-6,7$. Jumlah rerata bakteri paling rendah ditemukan pada perlakuan hari 0 dengan penambahan kombinasi kitosan 1,5 g dan kitosan 1,5\% $(\mathrm{C} 2 \mathrm{H} 0)$ yaitu sebanyak Log 3,5 sedangakan rerata bakteri paling tinggi ditemukan pada perlakuan hari ke 12 tanpa coating $(\mathrm{COH} 12)$ yaitu sebanyak $\log 6,7$. Nilai TPC dapat dilihat pada Gambar 1 .

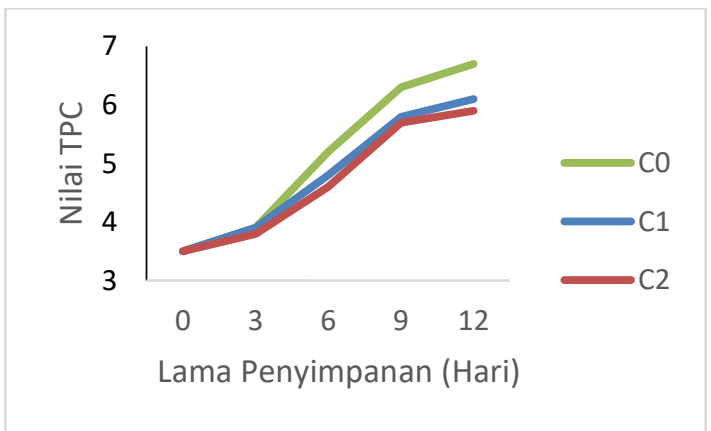

Gambar 1. Grafik TPC Fillet Kakap Merah

Gambar 1 menunjukan bahwa penggunaan coating dengan penambahan kombinasi kitosan 1,5 g dan cinnamon essential oil $1,5 \%$ berpengaruh nyata pada nilai TPC fillet ikan kakap merah. Hal ini membuktikan bahwa kitosan mempunyai kemampuan sebagai antibakteri dalam menghambat pertumbuhan mikroba. Lapisan tipis (edible coating) kitosan membungkus permukaan daging ikan menghambat masuknya $\mathrm{O}_{2}$ dan air sehingga menyebabkan mikroba menjadi sulit untuk berkembang [23].

Kitosan dengan konsentrasi 0,5\% sudah mempunyai kemampuan menurunkan jumlah bakteri [24]. Konsentrasi kitosan 0,50\% dan $0,75 \%$ mampu menurunkan jumlah bakteri pada cumi-cumi [25]. Konsentrasi kitosan $1,5 \%$ dapat menurunkan jumlah bakteri pada fillet ikan patin [26]. Hal ini membuktikan bahwa kitosan mempunyai aktivitas antibakteri sehingga dapat menghambat pertumbuhan mikroba. Kitosan memiliki gugus amina bebas $\left(\mathrm{NH}_{2}\right)$ yang pada saat dilarutkan dalam suasana asam (asam encer) akan terprotonasi menjadi gugus amino kationik $\left(\mathrm{NH}^{3+}\right)$ [27]. Gugus amino kationik $\left(\mathrm{NH}^{3+)}\right.$ yang dimiliki kitosan mampu bereaksi dengan permukaan sel mikroba yang bermuatan negatif, sehingga mengakibatkan depolarisasi membrane seluler mikroba sebagai akibat terganggunya integritas dinding sel dari hubungan kedua molekul yang menyebabkan kematian bagi mikroba [28].

Ikan masih dalam kategori segar jika jumlah bakterinya tidak melebihi $5.10^{5}$ (log TPC adalah 5,70 cfu/g) [29]. Ini berarti bahwa untuk total bakteri (TPC) pada fillet kakap merah tanpa coating ( $\mathrm{C} 0)$ dan fillet kakap merah dengan coating kitosan (C1) dengan penyimpanan suhu $6{ }^{\circ} \mathrm{C}$ dapat dikonsumsi sampai dengan penyimpanan hari ke 6, yaitu $\log 5,2$ dan Log 4,8. Sedangkan untuk fillet kakap merah dengan coating kitosan dan penambahan cinnamon essential oil $\left(\mathrm{CO}^{2}\right)$ dengan penyimpanan suhu $6{ }^{\circ} \mathrm{C}$ dapat dikonsumsi sampai dengan penyimpanan hari ke 9 yaitu Log 5,7.

\section{Total Volatile Base (TVB)}

Berdasarkan hasil penelitian diketahui bahwa rerata nilai TVB fillet Ikan kakap merah adalah 8,87-62,53 mg N/100 g. Jumlah rerata nilai TVB paling rendah ditemukan pada perlakuan hari 0 dengan penambahan kombinasi kitosan $1,5 \mathrm{~g}$ dan kitosan 1,5\% (C2H0) yaitu 8,87 mg N/100 g sedangakan rerata TVB paling tinggi ditemukan pada perlakuan hari ke 12 tanpa coating (COH12) yaitu $62,5 \mathrm{mg} \mathrm{N} / 100 \mathrm{~g}$. Nilai 
TVB dapat dilihat pada gambar 2 .

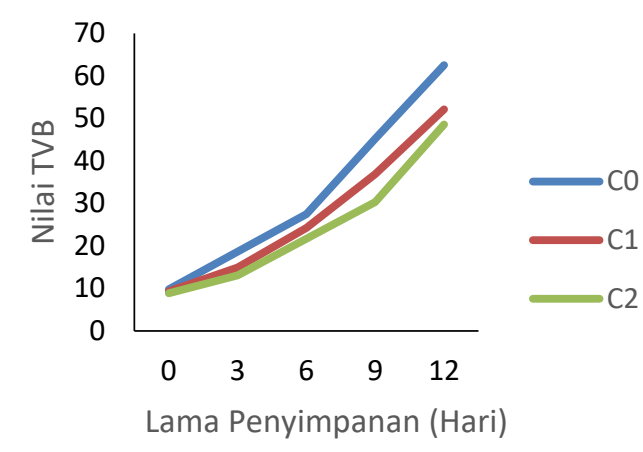

Gambar 2. Grafik TVB Fillet Kakap Merah

Gambar 2 menunjukan bahwa penggunaan coating dengan penambahan kombinasi kitosan 1,5 g dan cinnamon essential oil 1,5\% mempengaruhi nilai TVB fillet ikan kakap merah. Perlakuan Coating kitosan pada fillet ikan kod dan ikan herring menyebabkan penurunan nilai TVB sebesar $26-51 \%$ dibandingkan dengan fillet tanpa coating pada penyimpanan selama 12 hari [11]. Fillet ikan yang direndam dalam kitosan $1 \%$ selama tiga jam dapat mempengaruhi perlambatan kenaikan nilai TVB [30]. Larutan kitosan dapat memperlambat kenaikan nilai TVB secara drastis dan memperlambat proses pembusukan [31].

Berdasarkan nilai TVB kesegaran ikan, dibagi menjadi 4 kriteria yaitu: Ikan sangat segar mempunyai nilai TVB $<10 \mathrm{mgN} / 100 \mathrm{~g}$, ikan segar mempunyai nilai TVB antara 10-20 $\mathrm{mgN} / 100 \mathrm{~g}$, ikan masih bisa dikonsumsi yang mempunyai nilai TVB 20-30 mgN/100g, ikan tidak bisa dikonsumsi mempunyai nilai TVB lebih dari $30 \mathrm{mgN} / 100 \mathrm{~g}$ [32]. Berdasarkan parameter tersebut maka fillet kakap merah tanpa coating $(\mathrm{C} 0)$ dan fillet kakap merah dengan coating kitosan (C1) masih dapat dikonsumsi sampai penyimpanan hari ke 6 dengan nilai $27,53 \mathrm{mgN} / 100 \mathrm{~g}$ dan 24,27 $\mathrm{mgN} / 100 \mathrm{~g}$. Sedangkan fillet kakap merah dengan coating kitosan dan penambahan cinnamon essential oil (C2) masih dapat dikonsumsi sampai penyimpanan hari ke 9 yaitu $30,33 \mathrm{mgN} / 100 \mathrm{~g}$.

\section{pH}

Berdasarkan hasil penelitian diketahui bahwa rerata nilai $\mathrm{pH}$ fillet ikan kakap merah adalah 6,03-7,27. Jumlah rerata nilai $\mathrm{pH}$ paling rendah ditemukan pada perlakuan hari 3 dengan penambahan kombinasi kitosan 1,5 g dan kitosan 1,5\% $\left(\mathrm{C}_{2} \mathrm{H}_{3}\right)$ yaitu 6,03 sedangakan rerata $\mathrm{pH}$ paling tinggi ditemukan pada perlakuan hari ke 12 tanpa coating $\left(\mathrm{COH}_{12}\right)$ yaitu 7,27 . Nilai $\mathrm{pH}$ dapat dilihat pada Gambar 3.

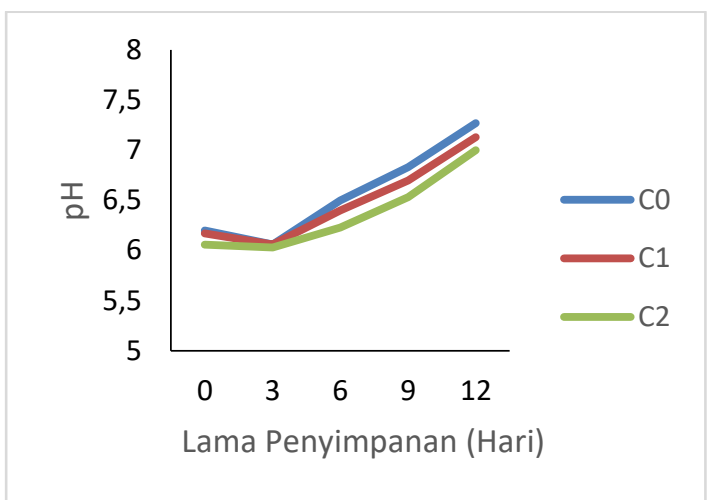

Gambar 3. Grafik pH Fillet Kakap Merah

Gambar 3 menunjukan bahwa nilai $\mathrm{pH}$ fillet ikan kakap merah pada perlakuan tanpa coating, dengan coating tanpa penambahan cinnamon essential oil dan dengan penambahan kombinasi kitosan 1,5 $\mathrm{g}$ dan cinnamon essential oil $1,5 \%$ pada hari ke 0 berturut-turut yakni, 6,20; 6,17; dan 6,06. Kemudian nilai $\mathrm{pH}$ mengalami penurunan pada hari ke 3 berturut-turut yakni, 6,06; 6,06; dan 6,03. Secara bertahap meningkat dari hari ke 6 sampai dengan hari ke 12. Hal ini diduga perlakuan kitosan mampu menghambat aktivitas bakteri sehingga penguraian protein oleh bakteri menjadi terhambat sehingga peningkatan kandungan nitrogen non protein yang dapat menyebabkan akumulasi basa juga ikut terhambat. Peningkatan nilai $\mathrm{pH}$ disebabkan akumulasi basa nitrogen [33]. Kitosan merupakan bahan yang dapat digunakan sebagai antibakteri karena memiliki kemampuan untuk menghambat pertumbuhan mikroorganisme perusak dan melapisi produk untuk melindungi produk dari kontaminasi lingkungannya [34]

Pembusukan ikan terjadi melalui 4 tahap, yaitu hyperanemia, rigor mortis, autolysis, dan bacterial decomposer [35]. Pada tahap ini terjadi penurunan dan kenaikan $\mathrm{pH}$ dalam setiap tahapnya selama penyimpanan. Pertama tahap hyperanemia (berlendir) $\mathrm{pH}$ masih netral, pada tahap rigor mortis (fase kejang/kaku) terjadi penurunan $\mathrm{pH}$ karena glikogen terhidrolisa menghasilkan 
akumulasi asam laktat. Selanjutnya autolysis tahap ini ikan menjadi lembek kembali, pH menurun disebabkan adanya aktivitas enzim dalam menguraikan protein yang menghasilkan asam amino, basa pirimidin dan purin, bersamaan dengan itu terjadi hidrolisis lemak menghasilkan asam lemak bebas dan gliserol. Tahap terakhir adalah bacterial decomposer atau penguraian yang dilakukan oleh bakteri terhadap ikan sehingga terjadi pembusukan.

Nilai $\mathrm{pH}$ ikan segar setelah ditangkap dilaporkan berada diantara 6,0 sampai 6,5 [36]. Ikan masih dapat diterima sampai $\mathrm{pH} 6,8$ tetapi menjadi busuk dengan $\mathrm{pH}$ di atas 7,0. Naiknya pertumbuhan bakteri pebusuk ditandai dengan naiknya nilai $\mathrm{pH}$ yang disebabkan oleh aksi sejumlah enzim pada jaringan ikan yang menghasilkan amoniak [37]. Berdasarkan parameter tersebut, fillet ikan kakap merah pada ketiga perlakuan masih termasuk ikan segar sampai hari ke 9. Perlakuan tanpa coating, coating tanpa cinnamon essential oil dan coating dengan kombinasi kitosan $1.5 \mathrm{~g}$ dan cinnamon essential oil $1.5 \%$ mempunyai nilai $\mathrm{pH}$ berturut-turut, 6,$83 ; 6,7$; dan 6,53 .

\section{SIMPULAN}

Penambahan cinnamon essential oil pada edible coating kitosan memberikan pengaruh terhadap kualitas fillet ikan kakap merah selama masa penyimpanan dilihat dari parameter TPC, TVB dan $\mathrm{pH}$. Fillet yang dilapisi dengan edible coating kitosan dengan penambahan cinnamon essential oil masih layak dikonsumsi sampai dengan penyimpanan hari ke 9 dengan nilai TPC Log 5,7; TVB 30,33 mgN/100g dan pH 6,53.

\section{SARAN}

1. Perlu dilakukan pengujian organoleptik untuk mengetahui penerimaan panelist terhadap fillet ikan kakap merah yang dicoating dengan kombinasi kitosan dan cinnamon essential oil

2. Perlu dilakukan pengujian antioksidan untuk mengetahui kemampuan edible coating kitosan dengan penambahan cinnamon essential oil dalam mempertahankan kualitas fillet ikan kakap merah selama masa penyimpanan.

\section{DAFTAR PUSTAKA}

[1] K. Sugama and B. priono, "Pengembangan budidaya ikan kerapu di Indonesia," War. Penelit. Perikan. Indones. Ed. akuakultur, vol. 9, no. 3, pp. 20-22, 2003.

[2] H. A. Sarwono, H. Minjoyo, and Sudjiharno, "Penerapan rekayasa teknologi pemeliharaan larva ikan kakap merah, Lutjanus johni secara massal di bak terkendali," Bulletin budidaya laut, pp. 9-14, 1999.

[3] S. Marzuki and R. Djamal, "Penelitian penyebaran, kepadatan stok dan beberapa parameter biologi induk kakap merah dan kerapu di perairan Laut Jawa dan Kepulauan Riau," $J$. Penelit. Perikan. Laut, no. 68, pp. 49 65, 1992.

[4] M. Badrudin and H. R. Barus, "Stok ikan bambangan (Lutjanidae) di perairan Pantai Utara Rembang, Jawa Timur," J. Penelit. Perikan. Laut, no. 53, pp. 61-68, 1989.

[5] A. M. Jacoeb and A. Saraswati, "KANDUNGAN ASAM LEMAK DAN KOLESTEROL KAKAP MERAH (Lutjanus bohar) SETELAH PENGUKUSAN," J. Pengolah. Has. Perikan. Indones., vol. 16, no. 2, pp. 168-176, 2014, doi: 10.17844/jphpi.v16i2.8051.

[6] A. S. Naiu, Y. Koniyo, S. Nursinar, and F. Kasim, Penanganan dan pengolahan hasil perikanan, 1 st ed. Gorontalo: CV. ATHRA SAMUDRA, 2018.

[7] B. Bahar, Memilih dan Menangani Produk Perikanan. jakarta: Gramedia Pustaka Utama, 2006.

[8] R. I. Wardani, S. A. Mulasari, F. Kesehatan, M. Universitas, and A. Dahlan, "Identifikasi Formalin Pada Ikan Asin Yang Dijual Di Kawasan Pantai Teluk Penyu Kabupaten Cilacap," Kes Mas J. Fak. Kesehat. Masy., vol. 10, no. 1, pp. 43-48, 2016, doi: 10.12928/kesmas.v10i1.5197.

[9] W. Mastuti, "Pengaruh Konsesntrasi $\mathrm{NaOH}$ dan Suhu pada Proses Deasetilasi Khitin dari Kulit Udang," Ekuilibrium, vol. 4, no. 1, pp. 21-25, 2005. 
[10] D. W. Lee, "Engineered chitosans for drug detoxification preparation, characterization and drug uptake studies," University of Florida, 2004.

[11] Y. J. Jeon, Y. V. A. Kamil, and F. Shahidi, "Chitosan as Edible Invisible Film for Quality Preservation of Herring and Atlantic Cod," J. Agric. Food Chem., vol. 50, no. 18, pp. 51675178, 2002.

[12] B. Kinzel, "Protein-Rich Edible Coatings For Foods," Agric. Res., vol. 40, no. 5, pp. 20-21, 1992.

[13] C. Winarti, Miskiyah, and Widaningrum, "Teknologi produksi dan aplikasi pengemas Edible antimikroba berbasis pati," J. Penelit. dan Pengemb. Pertan., vol. 31, no. 3, p. 30908, 2013, doi: 10.21082/jp3.v31n3.2012.p\%p.

[14] S. Quintavalla and L. Vicini, "Antimicrobial food packaging in meat industry," Meat Sci, vol. 62, pp. 373-380, 2002.

[15] M. R. Meena and V. Sethi, "Antimicrobial Activity of Essential Oils," Spices. J. Food Sci. Technol., vol. 31, pp. 68-70, 1994.

[16] R. M. R. Massilia, J. MosquedaMelgar, and O. M. Belloso, "Edible alginate-based coating as carrier of antimicrobials to improve shelf-life and safety of fresh-cut melon," Intl. $J$. Food Microbiol, vol. 121, pp. 313327, 2008.

[17] M. L. Balchin, Aromatheraphy Science, 1st Ed. London: Pharmaceutical Press, 2006.

[18] S. Fardiaz and Winarno, Keamanan Pangan: Bakteriologi. Bogor: Institut Pertanian Bogor, 1984.

[19] Suwetja, Metode Penentuan Mutu Ikan. Jilid I. Penentuan Kesegaran, Jilid 1. Manado: Universitas Sam Ratulangi, 1993.

[20] Suwetja, Biokimia Hasil Perikanan. Jilid III. Rigormortis, TMAO, dan $A T P$, Jilid III. Manado: Universitas Sam Ratulangi, 2007.

[21] A. Rozi, "Laju Kemunduran Mutu Ikan Lele (Clarias sp.) pada Penyimpanan Suhu Chilling," $J$. Perikan. Trop., vol. 5, no. 2, p. 169, 2018, doi: 10.35308/jpt.v5i2.1036.
[22] Nurjanah, T. Nurhayati, and R. Zakaria, "Kemunduran Mutu Ikan Gurami (Osphronemus gouramy) Pasca Kematian pada Penyimpanan Suhu Chilling," J. Sumberd. Perair., vol. 5, no. 2, pp. 11-18, 2011.

[23] El Ghaouth A, G. JA, B. N, A. A, and Belenger, "Effect of chitosan on cucumber plant supression of Phytium aphan denider matum and induction of defence reaction.," Phytopathology, vol. 84, p. 3, 1994.

[24] T. winarni Agustini and S. Sedjati, "The Effect of Chitosan Concentration and Storage Time on the Quality of Salted-Dried Anchovy (Stolephorus heterolobus)," J. Coast. Dev., vol. 10, no. 2, pp. 63-71, 2007.

[25] J. T. Murtini and A. Kusmarwati, "Pengaruh Perendaman Cumi Cumi Segar Dalam Larutan Kitosan Terhadap Daya awetnya Selama Penyimpanan Pada Suhu Kamar," Jurnal Pascapanen dan Bioteknologi Kelautan dan Perikanan, vol. 1, no. 2. p. $157, \quad 2007$, doi: 10.15578/jpbkp.v1i2.399.

[26] P. Suptijah, Y. Gushagia, and D. R. Sukarsa,

"PipihSuptijah_KajianEfekDayaHam bat," vol. XI, no. 0251, pp. 89-101, 2008.

[27] S. A. Sanford, C. J. Brine, and J. P. Zikakis, Advances in Chitin and Chitosan. London and New York, 1989.

[28] M. Kong, X. G. Chen, K. Xing, and H. Park, "Antimicrobial Properties of Chitosan and Mode of Action: A State of The Art Review.," Int. J. Food Microbiol., vol. 144, no. 1, pp. 51-63, 2010.

[29] SNI 01-2332.3-2006, “Cara uji mikrobiologi bagian 3: penentuan angka lempeng total (ALT) pada produk perikanan," Badan Stand. Nas., pp. 1-11, 2006.

[30] G. J. Tsai, W. H. Su, H. C. Chen, and C. L. Pan, "Antimicrobial Activity of Shrimp Chitin and Chitosan from Different Treatments and Applications of Fish Preservation.," Fish. Sci., vol. 68, pp. 170-177, 2002.

[31] C. M. E. Lopez, G. M. C. Gomez, M. 
M. Perez, and P. Montero, "A Chitosan-Gelatin Blend as A Coating for Fish Patties," Food Hydrocoll., vol. 19, pp. 303-311, 2005.

[32] L. Farber, Freshness Test. New York: Academic Press., 1965.

[33] V. Zaitsev, I. Kizevetter, L. Lagunov, T. Makarova, L. Minder, and V. Podsevalov, Fish Curing and Processing. Moscow: Mir Publisher, 2014.

[34] A. S. Murniyati and Sunarman, Pendinginan Pembekuan dan Pengawetan Ikan. Yogyakarta: Kanisius, 2000.
[35] L. Hardjito, “Aplikasi Kitosan Sebagai Bahan Tambahan Makanan dan Pengawet.," 2006.

[36] S. Köse and M. E. Erdem, "An investigation of quality changes in anchovy (Engraulis encrasicolus, L. 1758) stored at different temperatures," Turkish J. Vet. Anim. Sci., vol. 28, no. 3, pp. 575-582, 2004, doi: 10.1080/09637480701585511;18.

[37] N. W. Destrosier, Teknologi Pengawetan Pangan. Penerjemah Muhji Muljoharjo. jakarta: UI-press, 1987. 